\title{
黒鉛硝酸塩層間化合物の分解
}

\section{Decomposition of Graphite-Nitrate Lamellar Compound}

\author{
by
}

\author{
Michio Inagaki
}

(State University of New York at Buffalo)

The decomposition processes of graphite-nitrate and graphite-bisulfate lamellar compounds were found by the X-ray diffraction method to be different from each other. The first stage lamellar compound of graphite-bisulfate decomposed to the mixed stage of the second and third stages, and the further decomposition was observed as a gradual shift of $(001)$ diffraction lines. On the other hand, the second stage lamellar compound of graphitenitrate decomposed to the mixed stage of the third and fourth stages, and then decomposed to the residue compound directly. The third stage itself decomposed to the residue compound directly. There were no intermediate stages between the third or fourth stage lamellar compound and the residue compound. The decomposition of the graphite-bisulfate lamellar compound seemed to be caused from the decrease of the concentration of sulfuric acid by the absorption of water vapor, but the decomposition of graphite-nitrate to be caused from the vaporization of nitric acid.

\section{1. 緒言}

前報 1 では黒鉛酸性硫酸塩層間化合物の分解過程が従 来いわれているような $1,2,3, \cdots$ ステージと各ステージ を追って進む，いわゆる“peculiar step-wise”23)註)で はなく，混合ステージを通って進む，たとえば第 1 ステ 一シから第 2 と第 3 ステージの混合ステージ(以下 $(2+$ 3）混合ステージなどと記す) へと分解が進むこと,さら に層間化合物の分解生成物, すなわち残留化合物 ${ }^{4)}$ から 減圧および加熱処理によって層間化合物を得ることがで きることを報告した。その後，黒鉛酸性硫酸塩層間化合 物と同一分類に從来いれられている黒鉛硝酸塩層間化合 物について同様の検討を行なった結果, その分解過程は 酸性硫酸塩のそれとは異っていることが解った。ここで は酸性硫酸塩と比較しながら硝酸塩層間化合物の分解過

* State University of New York at Buffalo. 現在は名古屋大学工学部

註) 例えば第 2 ステージ ( 2 黒鉛層おきに $\mathrm{H}_{2} \mathrm{SO}_{4}$ と $\mathrm{HSO}_{4}^{-}$の 層がある)から第 3 ステージ ( 3 黒鉛層おき)へ分解する ためには黒鉛層間にある $\mathrm{H}_{2} \mathrm{SO}_{4}$ と $\mathrm{HSO}_{4}^{-}$とがいつたん全 部でて, 再び 3 層毎に入り直す必要があり, その意味で “pecliar”と彼等は呼んだ。
程を記し，さらにその機構について考察した。

\section{2. 実験および結果}

高純度化したセイロン産天然黒鉛を発煙硝酸中に浸漬 すると，膨鬥し，㬝間化合物を生ずる。これを一昼夜ほ ど室温に放置した後, X 線回折計 (ノレルコ) 用ガラス ホルダー上に取り出して, 時間の経過に伴うX線回折図 形の変化を測定した。結果の一例をFig. 1 に示す。発 煙硝酸中で生成する層間化合物は Rüdorff ${ }^{2)}$ の報告した 面間隔から第 2 ステージのものであると同定された。こ の第 2 ステージの層間化合物は空気中に放置することに よって $(3+4)$ 混合ステージに分解する。第 2 ステージ が全て分解し, その回折線が消失した後, この混合ステ 一ジは直接残留化合物に分解する。発烛硝酸中でも時に は第 3 ステージの層間化合物の生ずることがあった。第 3 ステージの層間化合物は空気中に放惪することによっ て，中間のステージを経ることなく直接残留化合物に分 解した (Fig. 2)。Fig. 2 には第 3 ステージの層間化合 物の（008) および（００10）回折線を同時に示した。第 3 ステージから残留化合物への分解の途中に中間のステ ージがもし生成しているのならば残留化合物の（002）と 


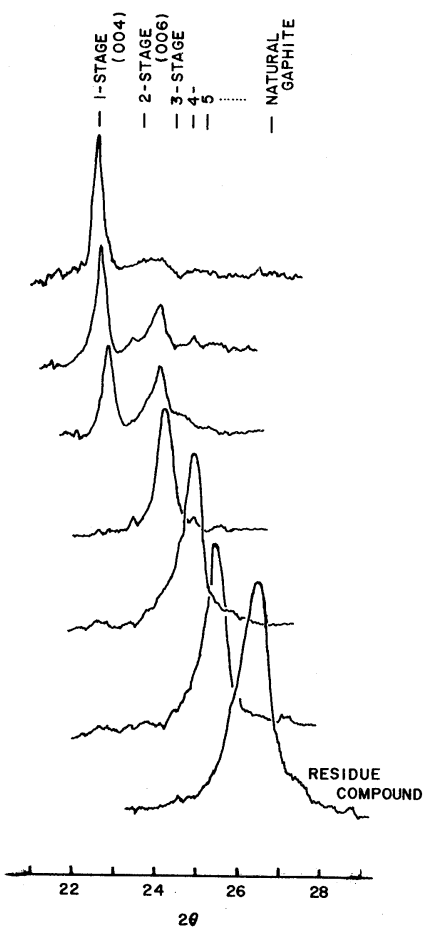

Fig. 1 Decomposition Process of GraphiteNitrate Lamellar Compound (2nd-stage)

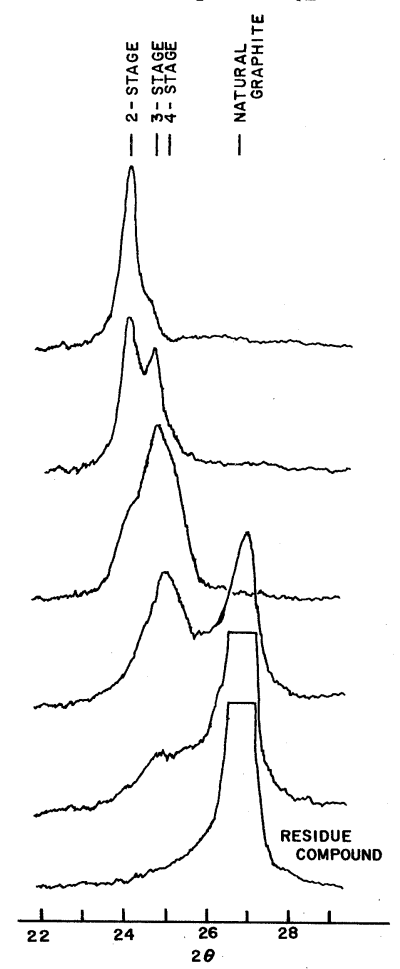

Fig. 2 Decomposition Process of GraphiteNitrate Lamellar Compound (3rd-stage)
第 3 ステージの $(008)$ 回折線招よび（0010）回折線の 間に各々 1 本の回折線ピークが現われるはずである（た とえばもし第 5 ステージが生じているならば $2 \theta \div 25.2^{\circ}$ および $29.5^{\circ}$ )。なお, Fig. 1 および 2 では必ずしも明確 に示されていないが，このようにして得た硝酸塩残留化 合物は原試料黒鉛よりも高角側に(002)回折線を持って いる。 この残留化合物の構造など詳細な点は別に報告す る予定である。

これに対して黒鉛酸性硫酸塩層間化合物の場合は，前 報 $^{1)}$ のように，分解は第1 ステージから混合ステージを 通りながら順次高次のステージに進み, $(2+3)$ 混合ス テージ以上では分解は単なる図形のシフトとして観測さ れる。そして最終的に残留化合物となる。Fig. 3 に濃硝酸 を少量加えた濃硫酸中で作った第 1 ステージの層間化合 物を空気中に放置して分解させた場合の回折図形の变化 を示した。

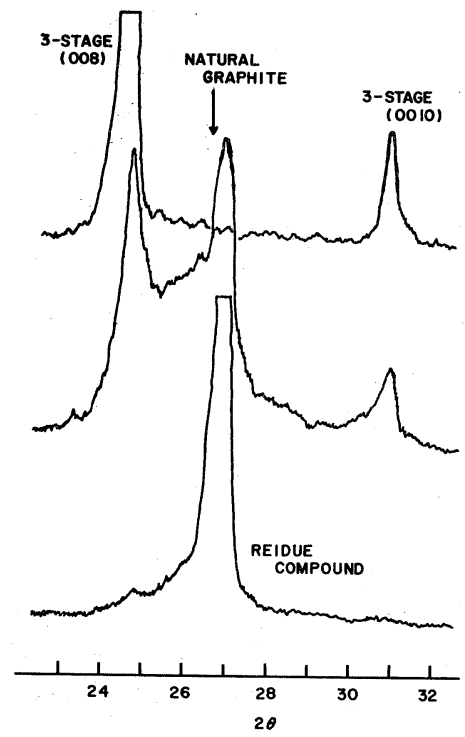

Fig. 3 Decomposition Process of GraphiteBisulphate Lamellar Compound (1st-stage)

酸性硫酸鉛層間化合物の分解はきわめて急速で, 第 1 ステージから $(2+3)$ 混合ステージへの分解は 10 分以 内で終ってしまった。そして, 高次のステージにゆくほ ど分解はゆっくりとなるが第 1 ステージから残留化合物 までの分解は数時間以内で終了してしまった。硝酸塩層 間化合物の分解はこれに比べればはるかに遅く, 第 2 ス テージは発煙硝酸中から取り出しても大約 3 時間ほど安 定で存在した。最終的に残留化合物にまで分解するには 1 昼夜を要した。

酸性硫酸塩の場合にはなお硫酸を多量に残している残 留化合物を減圧または加熱処理することによって瘅間化 
合物を得ることができた。結果をTable 1 にまとめて 示す。これに対して硝酸塩の場合には, 層間化合物を空 気中で分解して得た残留化合物を减圧下に 1 時間保った 時第 4 ステージの層間化合物が得られた。しかし减壬下 加熱処理をした場合には単なる残留化合物しか得られな かった。

Table 1 Formation of Lamellar Compound from Residue Compound

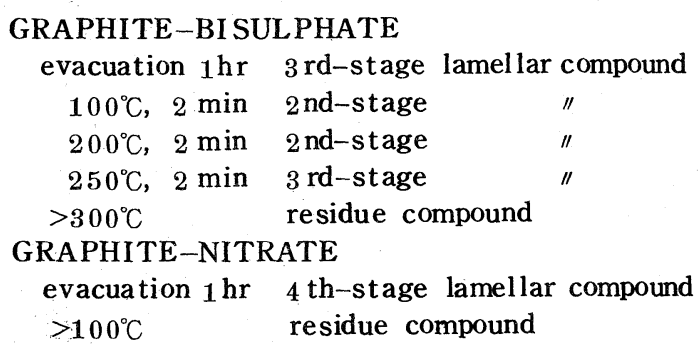

3. 考察

一般に黒鉛と酸が反応して生成する層間化合物はきわ めて分解し易く, 充分の量の酸が共存する時にのみ安定 で, 酸から分離することは不可能である。Rüdorff ${ }^{2)}$ は 酸性硫酸塭層間化合物をピ口燐酸の懸濁液として濃硫酸 から分離し得たと報告している。本実験では濃硫酸また は発煙硝酸から層間化合物を空気中に取り出して, その 分解過程をX線的に追跡したが，酸性硫酸塩と硝酸塩で は異っていることが明らかとなった。酸性硫酸塩の場合, 層間化合物の分解は主として共存濃硫酸が空気中の水分 を吸収し，その濃度が下がるために，その濃度と対応し たステージの層間化合物に分解するものと考えられる。 従って分解は順次段階的 (Rüdorff ${ }^{2}$, Riley $^{3}$ ) の云うよ うな“peculiar step-wise”ではないにしても)に進 む。事実, ガラスホルダー上で分解過程を追跡する途中 で硫酸㾋量が増し，時々洰紙で吸い取ってやる必要があ
ったこれに対して硝酸塩の場合，分解は硝酸が蒸発して 共存硝酸がなくなって行くことによると考えられ，反応 物が無くなるために第 3 第 4 ステージから直接残留化 合物に分解するものであろう。分解途中で試料は見掛上 乾いた状態で, 酸性硫酸塩の場合のように酸液があふれ るようなことは全くなかった。

残留化合物から層間化合物が生成する機構も上と全く 同様に考えられる。すなわち酸性硫酸塩の場合, 减王, 加熱処理によって残留化合物中で粒間などに存在してい た硫酸中の水分がうばわれて，その濃度が上り，黒鉛は その濃度に対応するステージの層間化合物に変る。した がって残留化合物中の硫酸の黒鉛に対する量によって生 成層間化合物のステージが決ると考えられる。充分水洗 し, 残存硫酸量が少いと考えられる残留化合物からは同 じ処理によっても㬝間化合物が得られなかったこと 上の考えを裏付けるものであろう。そして $250^{\circ} \mathrm{C}$ 以上に 加熱処理した場合は硫酸自体が蒸発するために，もはや 残留化合物しか得られなかったものであろう。これに対 して硝酸塩の場合, 減圧下加熱処理によっても層間化合 物が得られず，これは硝酸が蒸発し去るためであろう。 減圧処理によって第 4 ステージの層間化合物が得られた のはむしろ偶然で, 硝酸濃度が上ったためであろう。

本研究について御助言いただいた Prof. S. Mrozowski および野田稲吉教授に感謝の意を表します。

\section{引用交献}

1) M. Inagaki, Carbon, 4, $137(1966)$

2) W. Rüdorff, Z. Physik. Chem., B45, 42 (1939)

3) H. L. Riley, Fuel, 24, 8(1945)

4) G. R. Hennig, J. Chem. Phys., 19, 922 (1951)

5) M. Inagaki, Carbon (in the press) 